\title{
PENGEMBANGAN VARIASI OLAHAN BUAH NAGA MERAH MENJADI PRODUK PANGAN DALAM MENINGKATKAN KESEJAHTERAAN PETANI KARANG JOANG
}

\author{
Ria Setyawati\#1, Farida*2, Syahrul Karim"3, Nawang Retno Dwiningrum4, Tuatul Mahfud"5 \\ Program Studi Tata Boga, Politeknik Negeri Balikpapan \\ \#3syahrul.karim@poltekba.ac.id
}

\begin{abstract}
ABSTRAK
Pengolahan buah naga merah untuk dijadikan produk pangan saat ini sudah dilaksanakan oleh kelompok tani warga Karang Joang RT 19 KM 12 Balikpapan Utara, akan tetapi produk pangan yang dihasilkan belum bervariasi. produksi belum dapat dilakukan setiap hari, hanya pada waktu-waktu tertentu. Kelompok tani memiliki keinginan untuk mengolah buah naga menjadi produk olahan untuk mengatasi agar tidak mengalami kerugian akibat buah yang tidak terjual, akan tetapi salah satu kendala yang dihadapi adalah pengetahuan yang terbatas. Mereka belum memiliki pengetahuan cara pengolahan buah naga yang lebih bervariasi. Berdasarkan hasil observasi permasalahan mitra pada kelompok tani warna Karang Joang RT 19 dapat diidentifikasi sebagai berikut: 1) Bagaimana menambah variasi olahan buah naga untuk dapat menambah nilai ekonomi dan daya tahan simpan dalam bentuk produk sesuai dengan permintaan pasar saat ini, 2) Bagaimana memberikan produk olahan buah naga kepada konsumen dengan pengemasan dan labbeling yang tepat. Solusi yang ditawarkan berdasarkan uraian permasalahan mitra yang sedang dihadap diantaranya yaitu: 1) Pelatihan ketrampilan tekniks pengembangan pengolahan produk buah naga, 2) Pelatihan pengemasan dan labbeling produk olahan buah naga.
\end{abstract}

\section{PENDAHULUAN}

Potensi pengembangan buah-buahan lokal Kalimantan Timur, khususnya buah naga sangat besar dan sangat menarik minat petani untuk mengembangkannya. Keuntungan goegrafis katulistiwa menjadikan produksi buah naga di Kaltim tidak bergantung musim. Berbeda dengan buah naga di jawa yang sangat tergantung oleh musim (Ibrahim, 2013). Buah naga merupakan potensi buah lokal yang begitu besar dapat dikembangkan secara luas, sehingga dapat dikembangkan menjadi produk yang dapat dikonsumsi oleh masyarakat. Lahan usaha tani buah naga di kecamatan karang joang, Balikpapan sampai saat ini sekitar 100 ha, dengan pola panen per 10 hari dengan kapasitas produksi rata-rata untuk 1 ha adalah satu ton. Setiap tahun luasan usaha tani buah naga selalu mengalami peningkatan. Hal ini menunjukkan besarnya animo masyarakat untuk mengembaangkan budi daya buah naga karena selain prospek yang cerah, peluang pengembangannya masih terbuka luas. (Dinas Pertanian Tanaman Pangan Provinsi Kalimantan Timur 2013 dalam Rizal, 2015.

Dragon fruit atau biasa disebut dengan buah naga (buah dari tanaman Hylocereus undatus) merupakan buah yang pouler. Buah naga ini memiliki bentuk yang menarik, rasanya manis menyegarkan dan memiliki beragam manfaat untuk kesehatan. Sekilas rasa buah naga seperti buah kiwi, dengan kombinasi rasa yang manis, asam dan segar. Peluang usaha produk olahan buah naga masih sangat terbuka luas di Balikpapan karena buah naga memiliki beberapa kelebihan dibandingkan buah-buahan lainnya, diantaranya yaitu mempunyai khasiat yang bermanfaat bagi kesehatan. Sehingga biah naga dapat dijadikan sebagai bahan pangan fungsional.

Pengolahan buah naga untuk dijadikan produk pangan saat ini sudah mulai dilaksanakan. Produk yang sudah dibuat oleh warga karang joang $\mathrm{km} 12$, Balikpapan Utara saat ini antara lain : cimicimi buah naga, mie buah naga dan dodol buah naga. Biasanya produk yang dibuat sesuai dengan pesanan konsumen atau 
dititipkan pada koperasi, selain itu hanya dijual pada saat acara pameran. Sehingga produksi belum dapat dilakukan setiap hari, hanya pada waktu-waktu tertentu. Anggota kelompok yang masih aktif melakukan produksi hanya beberapa orang saja karena hanya sedikitnya variasi produk yang dibuat. Sedangkan dari keinginan warga ingin sekali mengolah buah naga menjadi produk olahan untuk mengatasi agar tidak mengalami kerugian akibat buah yang tidak terjual, akan tetapi salah satu kendala yang dihadapi adalah pengetahuan yang terbatas. Mereka belum memiliki pengetahuan cara pengolahan buah naga yang lebih bervariasi.

Berdasarkan permasalahan tersebut, perlu diadakannya pelatihan lagi, bagi warga karang joang, Sehingga saat ini dibutuhkan variasi produk yang dibuat, dengan seperti itu semua kelompok dapat berpartisipasi dalam produksi. Variasi jenis produk yang akan dibuat antara lain: permen, selai dan Dengan harapan jika semua dapat berpartisipasi, nantinya terdapat beberapa kelompok yang dapat memproduksi.

\section{PERMASALAHAN MITRA}

Berdasarkan pembahasan dan hasil observasi, maka permasalahan mitra dapat diidentifikasi sebagai berikut:

1. Bagaimana menambah variasi olahan buah naga untuk dapat menambah nilai ekonomi dan daya tahan simpan dalam bentuk produk sesuai dengan permintaan pasar saat ini

2. Bagaimana memberikan produk olahan buah naga kepada konsumen dengan pngemasan dan labbeling yang tepat.

\section{TARGET DAN LUARAN YANG DICAPAI Solusi Yang Ditawarkan}

Berdasarkan uraian permasalahan mitra di atas dapat ditentukan solusi dan sekaligus metode kegiatan yaitu "Pengembangan Variasi Olahan Buah Naga Merah Menjadi Produk Pangan Dalam Meningkatkan Kesejahteraan Petani Karang Joang Balikpapan" dalam menjawab permasalahan yang sedang dihadapi oleh mitra, yaitu diantaranya:
1. Pelatihan Ketrampilan Teknis
Pengembangan Pengolahan Produk Buah Naga

2. Pelatihan Pengemasan dan Labeling Produk Olahan Buah Naga

\section{Target Luaran}

Target utama pelaksanaan kegiatan Pengabdian Kepada Masyarakat ini adlah warga binaan dapat memiliki ketrampilan mengembangkan produk olahan buah naga dan dapat mengemas dan memberikan label pada produk olahan buah naga.

\section{METODE PELAKSANAAN}

Pelaksanaan dari r kegiatan
pengabdian masyarakat $\begin{array}{r}\text { tentang } \\ \text { "Pengembangan Variasi Produk Olahan } \\ \text { Buah Naga menjadi Produk pangan dalam } \\ \text { meningkatkan Kesejahteraan Petani Karang } \\ \text { Joang Balikpapan" dengan tahapan sebagai } \\ \text { berikut: }\end{array}$

1. Tahap pertama yaitu Survey Pada tahap ini dilakukan pendataan

2. Tahap Kedua yaitu Sosialisasi program pelatihan

Pada tahap ini yaitu memberikan informasi yang jelas kepada peserta pelatihan terhdap program pelatihan yang akan dilaksanakan

3. Tahap ke tiga yaitu Procurement (pengadaan alat dan barang)

Pada tahap ini melakukan pengadaan barang yang tepat dan sesuai dengan kebutuhan. Dengan mencari harga yang tepat dan cocok dan sesuai serta transparant dalam mendukung kegiatan pengabdian masyarakat ini.

4. Tahap ke empat yaitu Pelaksanaan Pelatihan

Pada tahap ini merupakan kegiatan ini dari program pelatihan yang terdiri kegiatan teori dan praktik. Kegiatan ini dilakukan selama 2 hari, pada hari 1 untuk kegiatan teori dan hari ke 2 untuk kegiatan praktik. Kegiatan praktik di laksanakan di ruang praktik (kitchen) Prodi Tata Boga Politeknik Negeri Balikpapan.

5. Tahap ke lima yaitu Pendampingan Pada tahap ini diberikan pendampingan secara berkelanjutan dan sistematis, untuk memastikan kualitas produk yang dihasilkan dan layak dipasarkan. Kegiatan pendampingan ini akan dilaksanakan beberapa bulan pasca pelatihan. 


\section{HASIL DAN PEMBAHASAN}

Sesuai dengan target luaran uyang akan dihasilkan di dalam pelatihan pengembangan variasi pengolahan produk buah naga sebagai upaya meningkatkan kesejahteraan petani Karang Joang Balikpapan, maka kegiatan yang dilakukan adalah:

1. Kegiatan survey untuk melakukan studi kelayakan potensi lokal buah naga yang dapat diolah menjadi permen dan selai. Selain itu mengenai peserta yang akan dilibatkan dalam kegiatan ini.

2. Sosialisasi

Pelaksanaan sosialisasi ini diberikan untuk memberikan informasi yang lebih jelas terhadap program pengabdian yang akan diselengarakan, berikut ini kegiatan yang terdapat di dalam program tersebut dan rencana pelaksanaan. Tujuan dari sosialisasi ini antara lain:

Untuk memberikan informasi dan gambaran kepada kelompok masyarakat khususnya calon penerima manfaat dan aparat RT, tentang kelanjutan kegiatan seperti yang sudah pernah dilakukan sebelumnya. Sehingga usaha peengelohan hasil pangan lokal ini dapat lebih berkembang.

Memberikan motivasi kembali kepada anggota kelompok yang mungkin sudah berkurang keaktifannya sehingga dapat lebih bersunguhsungguh dalam mengelola usaha produk pangan.

Melakukan kesepakatan mengenai rencana pelaksanaan kegiatan penyuluhan, pelatihan dan pendampingan

3. Pengadaan Bahan Peralatan

Pengadaan bahan dan peralatan dilakukan untuk memenuhi kebutuhan bahan dan peralatan disesuaikan dengan jumlah kelompok dari peserta. Selain itu diadakan sesuai dengan aspek yang dibutuhkan, harga yang sesuai dan efisien serta transparant dalam mendukung kegiatan pengabdian tersebut. Bahan dan peralatan digunakan pada saat pelatihan dan setelah kegiatan selesai peralatan dan sisa bahan dihibahkan dengan peserta sebagai investasi dan modal usaha yang akan dikembangkan.

4. Pelaksanaan Pelatihan

Kegiatan ini dimulai dengan pemberian teori mengenai resep yang akan digunakan untuk praktik. Terutama mengenai pengetahuan bahan pangan, peralatan dan cara pengolahan buah naga, dan pengemasan sehingga dapat dijadikan permen dan selai sehingga layak untuk dijual. Kegiatan dilanjutkan dengan praktik membuat selai dan permen sampai pada proses pengemasan.

5. Pendampingan

Kegiatan ini dilakukan secara berkelanjutan dan sistematis. Kelompok tani membuat selai dan permen di rumah salah satu warga. Pendampingan dimulai dari pemilihan bahan, saat pengolahan dan pengemasan selai dan permen.

\section{KESIMPULAN DAN SARAN}

Berdasarkan hasil pelaksanaan kegiatan program Pengabdian Masyarakat dapat disimpulkan bahwa:

1. Program pengabdian masyarakat ini memberikan dampak terhadap pengetahuan dan perilaku para petani untuk dapat mengolah buah naga lebih bervariasi

2. Menyediakan bantuan alat pengolahan dan kemasan untuk produk selai dan permen.

3. Secara keseluruhan kegiatan pengabdian masyarakat dari perguruan tinggi sangat diharapkan oleh masyarakat dalam mengimplementasikan ilmu dan hasil penelitian ditengah-tengah masyarakat.

\section{Saran}

1. Koordinasi dan komunikasi yang efektif pada semua stake holder pelatihan baik dengan masyarakat maupun dengan tim pelaksana serta partner lain yang terlibat mutlak diperlukan sehingga dapat bersinergi dengan baik dalam mencapai tujuan program ini.

2. Gagasan/ ide ide serta saran saran yang muncul dari bawah (warga) 
hendaknya diperhatikan dan ditindaklanjuti dengan baik melihat besarnya minat warga untuk dapat mengembangkan usaha di bidang pengolahan makanan ini.

\section{DAFTAR PUSTAKA}

Faridah, A., Pada, K.S., Yulastri, A. and Yusuf, L., 2008. Patiseri Jilid 3. Jakarta: Depdiknas.

Hariono, B. and Bakri, A., 2016. Peningkatan Produktivitas Keripik Buah melalui Aplikasi Vakum Very High (VH). Prosiding.

Herudiyanto, M.S., 2008. Teknologi pengemasan pangan. Bandung: Widya Padjadjaran.

Riskiawan, H.Y., Purnomo, B.H., Abdurahman, A., Hariono, B. and Puspitasari, T.D., 2018, January. Strategy of Trade-Reliable Featured Product Supporting Regional Innovation Systems. In Journal of Physics: Conference Series (Vol. 953, No. 1, p. 012117). IOP Publishing.

Wahyu A, 2016. Membuat Aneka Olahan Selai Buah. Gudang Penerbit. 